\title{
Evaluation of the Suitability of a Composite Liner System for Designing a Landfill Bioreactor on Confined Bedrock at Sammanthurai in Sri Lanka
}

\author{
R. Thivyatharsan, H.A.Y.R Gunarathna, B.F.A. Basnayake \\ L.W. Galagedara ${ }^{1}$ and P. Kuruparan \\ Center for Renewable Energy Sources (CRES) \\ Postgraduate Institute of Agriculture \\ University of Peradeniya \\ Sri Lanka
}

\begin{abstract}
The development of a low cost and environmentally friendly liner system is essential for countries like Sri Lanka because the high-density polyethylene liner is of high cost and much more prone to toxic conditions and failures. This research was carried out at Sammanthurai by using clay-waste polyethylene-clay composite liner and permeability tests were conducted that gave values between $6.3 \times 10^{-8}$ and $2.6 \times 10^{-8} \mathrm{~cm} \mathrm{sec}^{-1}$ under both saturated and unsaturated conditions at the hydraulic head of $86.2 \mathrm{~cm}$. These low permeability values were achieved by laying and compacting one layer after another at the required soil consistency to make a composite liner system. In addition, the use of waste polyethylene based composite liner is more beneficial than the high density polyethylene liner because this waste polyethylene makes an active biofilter which is cheaper and environmentally friendly. The ground penetrating radar survey shows that the confined bedrock is 0.5 to $6.0 \mathrm{~m}$ and the water table is 0.4 to $0.5 \mathrm{~m}$ from the surface during the rainy season. Therefore, permeate from the liner system will accumulate in the drainage layer above the confined bedrock and that can lead to embankment failure. It is then very important to install a collection and management system to accommodate permeates that were $3.51 \times 10^{-2} \mathrm{~cm} \mathrm{sec}^{-1}$ and $3.86 \times 10^{-2} \mathrm{~cm}^{3} \mathrm{sec}^{-1}$ under saturated and unsaturated conditions, respectively. The 'water permeates' will be reused, thus, overcoming the lack of available water in the dry zone of Sri Lanka for managing wastes as a resource.
\end{abstract}

\section{INTRODUCTION}

Landfills have been widely used for municipal solid waste (MSW) disposal all over the world. In developing countries, it is considered as a reliable and a cost effective method if adequate land is available. A bioreactor landfill is a sanitary landfill that uses enhanced microbiological processes to transform and stabilize the readily and moderately decomposable organic waste constituents within 5 to 10 years of bioreactor process implementation (Reinhart et al., 2002). The process requires significant liquid addition through leachate recirculation to reach and maintain optimal conditions (Reinhart et al., 2002).

There has been a trend to shift the landfill design concept from "dry cell" approach towards "wet cell" approach since some researches have proven that continuance of optimum moisture content in landfill can accelerate the waste establishment process (Al-Yousfi and

Department of Agricultural Engineering, Faculty of Agriculture University of Peradeniya, Sri Lanka 
Pohland, 1998; Barlaz and Reinhart, 2004). The wet condition is mostly achieved by leachate recirculation (Reinhart and Townsend, 1998; Yuen et al., 2001; Wang et al., 2006) in addition to permeate recirculation and external water or treated leachate addition (Sanphotia et al., 2006). The positive aspect of additional cost of collection is the reuse of precious water needed for proper function of a landfill bioreactor under very dry conditions in the east coast of Sri Lanka. Although a higher rate of liquid application can enhance the biological degradation in relation to landfill stabilization and gas productions, a comprehensive understanding of hydrological performances of a bioreactor is more crucial since all these processes are mostly related to each other (Yuen et al., 2001). In considering hydrological parameters with other factors, the High Density Poly Ethylene (HDPE) liner is identified as one of the constraints due to building up of inorganic compounds and lately, breaching of liner has become a crucial issue.

It was found that large quantities of wasted polyethylene films are remaining in dumpsites, which cannot be recycled and/or reused directly. Thus, use of such polyethylene films in landfill construction would give an added advantage in dumpsite rehabilitation work. The development of the liner system technology using waste polyethylene was carried out at the University of Peradeniya and a very low hydraulic conductivity was obtained (Gunarathna $e t$ al., 2007). However, to achieve good composite action, good hydraulic contact between the geo-membrane and underling clay soil where the geo-membrane should not be separated from the clay with permeable material is required (Reinhart and Townsend, 1998). The principle hypothesis is that a sandwich type arrangement of clay-waste polyethylene-clay performs better than a clay liner with the same thickness and physical properties. Thus, this paper focuses on the possibility of developing the composite biofilter liner above a confining layer and evaluating the performance with the existing liner system. The selection of the best location for the construction of a landfill bioreactor within the Science Park of the South Eastern University was inclusive of the study.

\section{MATERIALS AND METHODS}

\section{Site investigation}

Ground Penetrating Radar (GPR) was used to investigate the soil profile and location of the bed rock and groundwater table at the proposed site along 3 different survey lines in NorthSouth (2) and East-West (1) directions in November 2008. Two North-South transects were 194 and $49 \mathrm{~m}$ long while the East-West transect was $147 \mathrm{~m}$ long. In all of these transacts, reflection survey mode was used with $100 \mathrm{MHz}$ frequency antenna having $1.0 \mathrm{~m}$ antenna separation and $0.5 \mathrm{~m}$ step size (Galagedara et al., 2003; Galagedara, 2003). In addition, several Common Mid Point (CMP) surveys were also conducted in estimating the average GPR wave velocity (Galagedara et al., 2003) which is needed to estimate the exact depth to the bed rock and/or water table. In all GPR surveys conducted at this site, $260 \mathrm{~ns}$ time window and 128 stacks were used. When developing the profile section of the subsurface, both horizontal and vertical filtering as well as different gain functions were used to clearly identify the subsurface events (Sensors and Software Inc, 2006).

\section{Construction of a test-cell}

The landfill bioreactor test-cell of $20.8 \mathrm{~m} \mathrm{x} 18.3 \mathrm{~m}$ was constructed at Malwatta in Sammanthurai as shown in Fig. 1. The main components to envelope the containment are sub base, embankments, liner system, permeate collection and removal system and cover. 


\section{Sub-base and embankments}

The land clearing and grading was done using JCB excavator. After that, the sub-base was constructed using existing soil surrounding the location. The soil was compacted by using a plate compactor to construct the sub-base. The existing soil in the site was excavated and spread by placing $15 \mathrm{~cm}$ thick layer by layer and compacted until it reached $1.3 \mathrm{~m}$ embankment height. The embankment was constructed to have a $0.9 \mathrm{~m}$ top, $4.0 \mathrm{~m}$ bottom width and $40^{\circ}$ slopes on both sides, initially. Then, slopes of both sides were changed to $30^{\circ}$ because of liner failure on the inner side of embankment. A 1000 gauge $(250 \mu \mathrm{m}$ thick) polyethylene sheet was laid at the bottom and sides of the test-cell to collect the permeate from the liner.

\section{Permeate drainage and collection layer}

The channel was made in the middle of the test-cell base with a $2^{0}$ slope towards one end of the cell and both sides of the channel also had $2^{0}$ slopes towards the middle channel. A 50 $\mathrm{mm}$ diameter perforated PVC pipe was laid on the sheet along the channel towards the outlet while covering with a $2 \mathrm{~mm} \times 2 \mathrm{~mm}$ mesh size geonet. The perforated PVC pipe and the bottom area were covered by a $15 \mathrm{~cm}$ river sand layer on the polyethylene sheet as a drainage blanket before constructing the liner. This system of drainage will facilitate to collect all the water, which drains through the drainage blanket into the perforated PVC pipe.

\section{Clay-waste polyethylene-clay composite liner}

The first clay liner applied was $6 \mathrm{~cm}$ thick and then compacted to $5 \mathrm{~cm}$ using a plate compactor. The $15 \mathrm{~cm}$ thick waste polyethylene layer was laid above the first clay layer and the thickness was reduced to about $5 \mathrm{~cm}$ after compaction using the same compactor. On the polyethylene layer, a $6 \mathrm{~cm}$ thick clay layer was applied and compacted to $5 \mathrm{~cm}$ to complete the clay-waste polyethylene-clay composite liner. The sides of the embankment and bottom of the cell were compacted using this plate compactor to achieve low permeability as well as the required strength. A water head manometer and a control valve were fixed at the end of the drainage pipe (perforated PVC pipe) that collects all the drainage water into a tank system. The liner permeability was tested by measuring the rate of water collected by the pipe installed at the bottom. The experiment was carried out for the water head of $86.2 \mathrm{~cm}$ and permeability under both conditions of saturated layer beneath the liner (simulated by a sand layer) and unsaturated layer beneath the liner were calculated. Fig. 1 shows the conceptual design of the experiment.

\section{Liner testing}

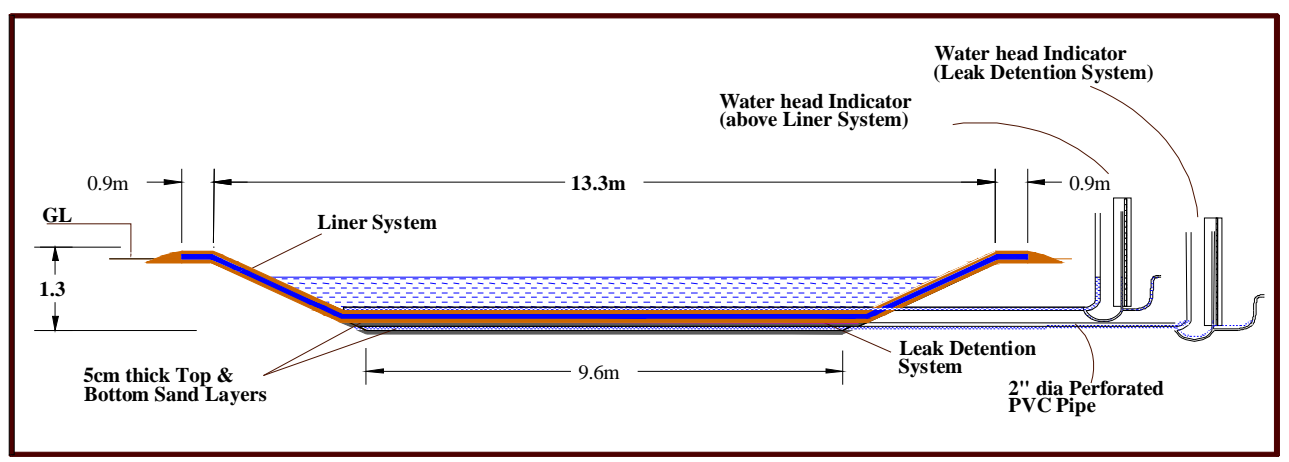

Fig. 1. Conceptual design of the test-cell 


\section{Measurement of hydraulic conductivity of liner}

As proposed by Qian et al., (2002), the modified Darcy's equation (Eq. 1) was fit to these experimental conditions.

Where;

$$
\frac{Q}{A T}=K_{s} \frac{\Delta H}{\Delta l}
$$

Eq. 1

$=$ Flux $\frac{Q}{A T}(\mathrm{~cm} / \mathrm{s})$

Eq. 2

$=\quad \frac{\Delta H}{\Delta l}$ Hydraulic Gradient $(\mathrm{cm} / \mathrm{cm})$

Eq. 3

$$
K_{s}=\text { Hydraulic Conductivity }(\mathrm{cm} / \mathrm{s})
$$

Total volume of permeate $=$ Permeate through bottom + Permeate through slope sides

$$
Q_{\text {Total }}=\left(K_{c} \times A_{\text {bottom }} \times t \times \frac{\Delta H}{\Delta L}\right)+\left(K_{c} \times A_{\text {angle }} \times t \times \frac{\Delta H}{\Delta L}\right)
$$

Drainage blanket beneath the liner was filled with water to create a saturated condition. Likewise, the water from the drainage blanket was removed to create unsaturated condition and then $\mathrm{K}$ was calculated under both conditions.

\section{RESULTS AND DISCUSSION}

\section{Site investigation}

According to the GPR survey results, the bedrock is located very near to the surface along the entire survey line of the transect 1 in North-South direction (event "A" in Fig. 2). The depth of the bedrock varied from 0.5 to $6.0 \mathrm{~m}$. In some places (from 140-190 m section), the bedrock is located at the surface and/or just below the surface. These positions were verified by soft drilling at several places on the survey line. This bedrock is potentially fractured due to multiple reflections observed in all three survey lines. These fractures are very prominent in some places along the survey lines and even to some depths as shown by event "B". The event " $\mathrm{C}$ " potentially is a lithological boundary or a very big fracture in the bedrock. This needs verification by taking an undisturbed core sample at this point. The water table was found to be within $0.4-0.5 \mathrm{~m}$ in this study area based on the reflection results from all the survey lines and it is clear in the reflection profile as well (Fig. 3).

According to the GPR survey, this location was selected for constructing the above-ground landfill bioreactor because the bedrock is just below the soil surface and also due to the shallow water table. Because of the fractured bedrock in most of the places in this site, the water table is on the surface and/or just below the surface during heavy rains. This will affect the liner and the embankment of the landfill bioreactor. Therefore, a proper drainage and collection system is essential 


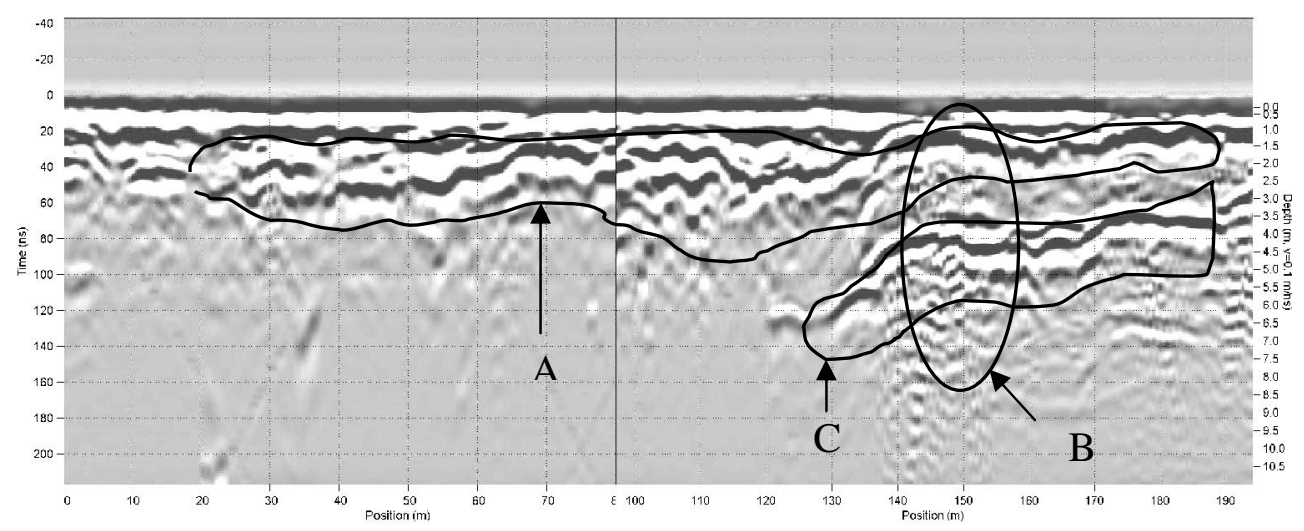

Fig. 2. High frequency geophysical profile obtained using $100 \mathrm{MHz}$ GPR antenna along a $194 \mathrm{~m}$ length in N-S direction at the proposed landfill site

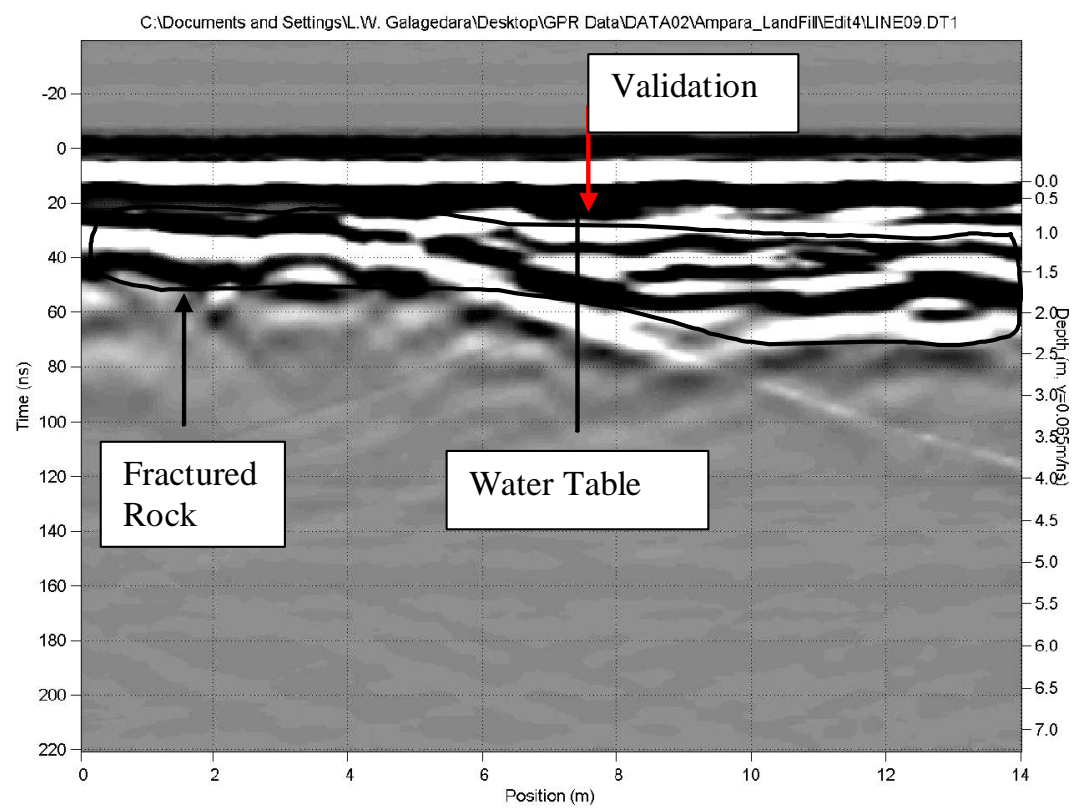

Fig. 3. High frequency geophysical profile along a shorter distance to map the water table

\section{Field scale experiment of landfill bioreactor}

\section{Liner permeability}

The results and the analysis gave a hydraulic conductivity value for the hydraulic head of $86.2 \mathrm{~cm}$. It took 15 to 25 hours to reach steady state conditions. This process showed two distinguished phases as shown in Fig. 4. At the beginning, a negative natural logarithm value determined the hydraulic conductivity and then the system reached the steady state condition. The permeability of the liner was calculated based on the data obtained during steady state conditions. 


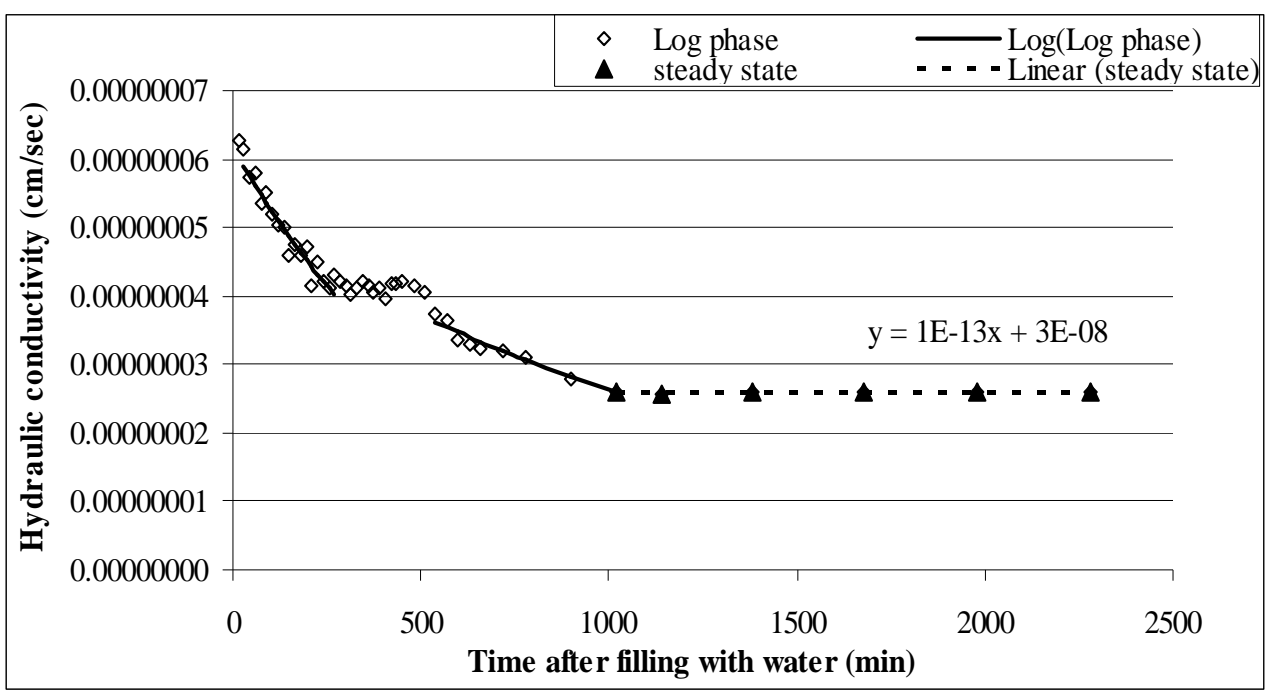

Fig. 4. Field scale liner permeability variations at the hydraulic head of $86.2 \mathrm{~cm}$

These results were analyzed and evaluated to determine the hydraulic conductivity for the two conditions of saturated and unsaturated. Notably, in both cases, the linearity was maintained at saturated levels and Darcy's equation (Eq. 1) was used to calculate the hydraulic conductivity (Qian et al., 2002). Fig. 5 illustrates the variations in the hydraulic conductivity for hydraulic head of $86.2 \mathrm{~cm}$ under both saturated and unsaturated conditions. Even though both hydraulic conductivities vary between $2.6 \times 10^{-8}$ and $6.3 \times 10^{-8} \mathrm{~cm} \mathrm{sec}^{-1}$, the unsaturated hydraulic conductivity was higher in the earlier stage due to higher hydraulic gradient created after sudden removal of water underneath the liner. It has been shown that unsaturated hydraulic conductivity decreases over a longer period of time when the hydraulic gradient decreases and become a normal gradient (without suction) and attain steady state with time (Gunarathna et al., 2007).

The standard hydraulic conductivity value for compacted clay liners is $1.0 \times 10^{-7} \mathrm{~cm} \mathrm{sec}^{-1}$ or below (Quan et al., 2002). Thus, the results were above the minimum requirement for landfill liners at very high estimated leachate head. It is also expected to reduce hydraulic conductivity with time mainly due to reduction in pore spaces in the liner. In addition to these findings, the hydraulic conductivity values under both conditions of saturated and unsaturated beneath the liner (simulated by a sand layer) fluctuated within a very narrow margin. Therefore, it can be deduced that liner permeability will not increase or decrease very much when the water table fluctuates from a lower value to a higher value affected by the seasonal variations of dry to wet conditions, respectively.

The key factor for the success of the liner system was the understanding of the need to compact the layers in stages to sandwich the polythene between the clay layers. The applied compaction on constructing the liner of the test cell satisfactorily achieved a low hydraulic conductivity value, which was within an acceptable range of impermeability for landfill liners. 


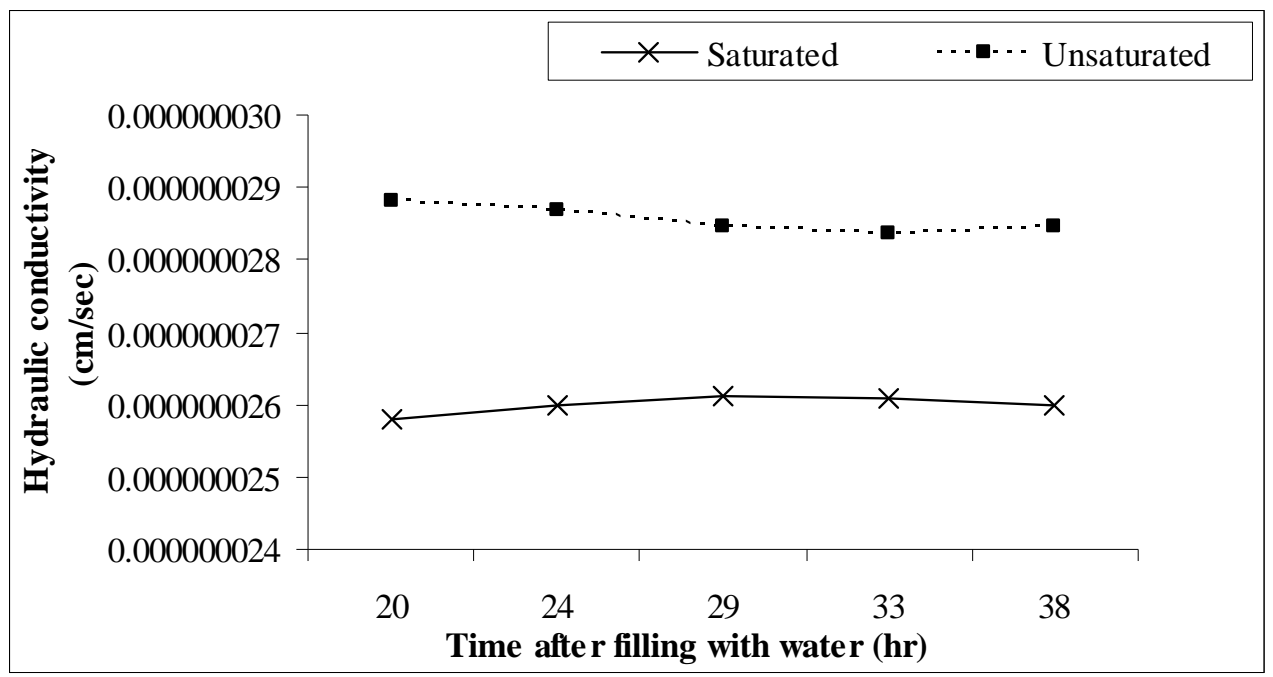

Fig. 5. Hydraulic conductivity of the field scale liner at hydraulic head of $86.2 \mathrm{~cm}$ in saturated and unsaturated conditions

\section{Effect of pore water pressure on the liner and the embankment}

The permeate from the liner took 1 to 2 days to saturate the soil underneath the liner and above the bedrock (confined layer), when no permeate collection system was used. During this period, the rate of permeate from the liner was $3.51 \times 10^{-2} \mathrm{~cm}^{3} \mathrm{sec}^{-1}$. Under this saturated condition, the pore water pressure potentially increases with the accumulation of water in the drainage layer and it will have an increased load on the embankment and the bottom of the liner. Therefore, there is a chance for the failure of the embankment due to sliding, but there will only be small sinking of the landfill bioreactor because of the shallow bedrock. Figure 6 shows the cumulative quantity of permeate from the liner under saturated and unsaturated conditions. Under the unsaturated condition, the rate of permeate was $3.86 \times 10^{-2} \mathrm{~cm}^{3} \mathrm{sec}^{-1}$. This will be collected through the permeate drainage and collection system to overcome the high pore water pressure mentioned above.

\section{Permeate collection and removal system}

Permeate collection and removal system is located below the liner that consists of highly permeable sand. As bioreactor landfill uses permeate recirculation technique, the permeate collection system must be carefully designed to collect higher volume of water. An encasement of the pipe with locally available gravel provided free flow under unsaturated conditions. It will also prevent clogging with fine particles. The drainage layers promoted seepage of the drained permeate to the collection pipes. In the case of applying the technology in large scale landfill bioreactors, the cost is less if sandy soil is available at the site rather than river sand is used. 


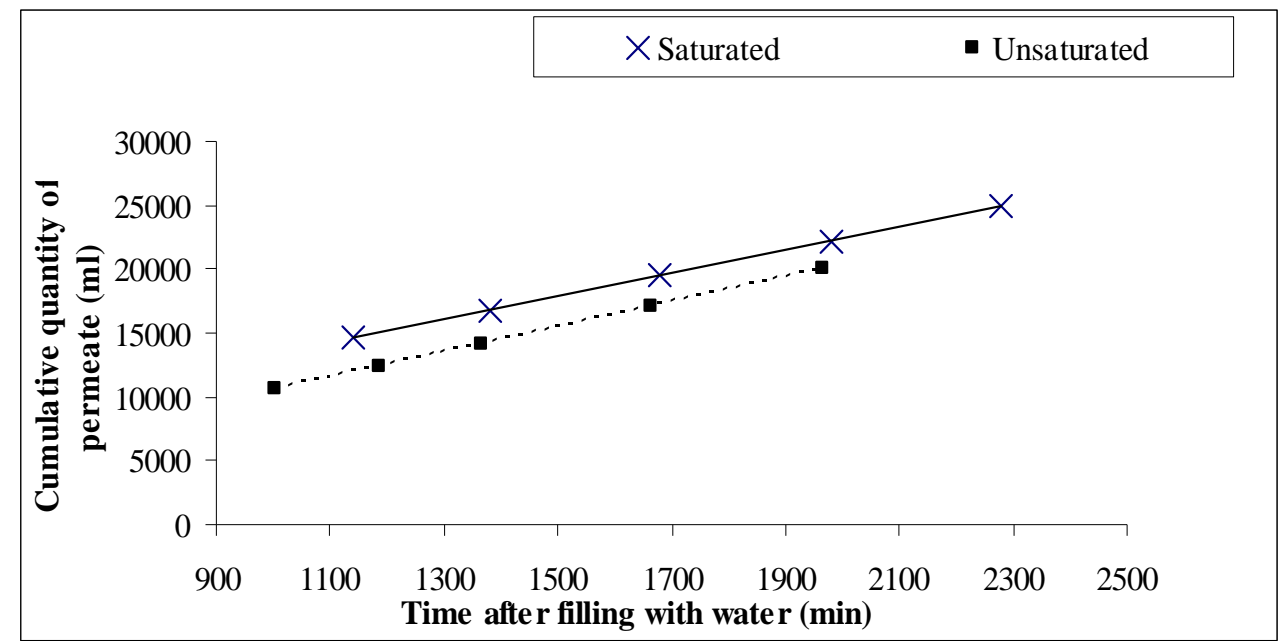

Fig. 6. Cumulative quantity of permeate from the liner under saturated and unsaturated conditions

\section{Comparison of clay-waste polyethylene-clay composite liner with the HDPE liner}

In case of landfill bioreactor, this clay-waste polyethylene-clay composite liner is functioning better than the HDPE liner because it is possible to maintain high leachate heads, since large quantities of leachate is required for operating the landfill bioreactor to reach the optimum waste moisture content. In fact, allowable leachate head of $300 \mathrm{~mm}$ above the HDPE liners is insufficient to store the required moisture content over the prolonged dry periods experienced in the dry zone conditions of Sri Lanka.

\section{CONCLUSIONS}

The GPR survey provided adequate information on the specific features of the site. The findings are that the bedrock is near to the surface and the thickness recorded was six meters and the bedrock potentially fractured due to multiple reflections and these fractures are very prominent in some places. Thus, the liner system above this rock is an important factor to be considered in the design.

The effectiveness of the clay-waste polyethylene-clay liner demonstrated reached very satisfactory results, even better than at Peradeniya. It could be attributed to larger scale application and the type of soil in Sammanthurai. The practical experience gained under dryer conditions is useful for constructing the full-scale landfill bioreactor in the dry zone of Sri Lanka. The live biofilter liner made from waste polyethylene is an environmentally friendly application and is very much cheaper and better than HDPE liner that often fails. However, a greater understanding of permeate collection and management system is very important, especially in this geographical area because of the confined layer to prevent failure from sliding of embankment. In addition, the collection of permeate will be reused for proper function of landfill bioreactor under very dry conditions in the dry zone of Sri Lanka. 


\section{ACKNOWLEDGEMENT}

The Authors are most grateful to the United Nations Office for Project Services for financial support given for the research. Special thanks to Faculty of Applied Science, South Eastern University of Sri Lanka for the land and assistance given for the research. National Research Council of Sri Lanka provided financial support for the GPR system.

\section{REFERENCES}

Al-Yousfi, B. and Pohland, F.G. (1998). Strategies for simulation, design, and management of solid waste disposal sites as landfill bioreactors. Practice Periodical of Hazardous, Toxic and Radioactive Waste Mgt. 2(1): 13-21.

Barlaz, M.A. and Reinhart, D. (2004). Bioreactor landfills: progress continues-editorial. Waste Mgt. 24: 859-860.

Galagedara, L.W. 2003. The GPR Direct Ground Wave Method for Soil Moisture Content Estimation: Field Experiments and Modeling. Unpublished PhD Thesis, University of Guelph, Canada.

Galagedara, L.W., Parkin, G.W. and Redman, J.D. (2003). An analysis of the GPR Direct Ground Wave Method for soil water content measurement. Hydrol. Processes 17: 36153628 .

Gunarathna, H.A.Y.R., Kapukotuwa, A.S.B., Karunarathna, A.K. and Basnayake, B.F.A. (2007). Construction and evaluation of a low cost, wasted polyethylene based liner for small landfills. Proceeding of the International Conference on Sustainable Solid Waste Mgt. 226233.

Qian, X., Koerner, R.M. and Gray, D.H. (2002). Geotechnical aspects of landfill design and construction. Prentice-Hall, New Jersey.

Reinhart, D.R., McCreanor, P.T. and Townsend, T. (2002). "The bioreactor landfill - its status and future". Waste Mgt. and Res. ISWA 30:172-186.

Reinhart, D. R. and Townsend, T. G. (1998). Landfill Bioreactor Design and Operation. Lewis publisher, Boca Raton, Florida, USA.

Sanphotia, N., Towprayoona, S., Chaiprasert, P. and Nopharatan, A. (2006). The effects of leachate recirculation with supplemental water addition on methane production and waste decomposition in a simulated tropical landfill. J. of Envt. Mgt. 81: 27-35.

Sensors and Software Inc. (2006). PulseEKKO PRO users guide, Mississauga, ON, Canada.

Wang, Q., Matsufuji, Y., Dong, L., Huang, Q., Hirano, F. and Tanaka. A. (2006). Research on leachate recirculation from different types of landfills. Waste Mgt. 26: 815-824.

Yuen, S.T.S., Wang, Q.J., Styles, J.R. and McMahon, T.A. (2001). Water balance comparison between a dry and a wet landfill- a full-scale experiment. J. Hydrol. 251: 29-48. 